\title{
Identification of Parvalbumin and Two New Thermolabile Major Allergens of Thunnus tonggol Using a Proteomics Approach
}

\author{
Misnan Rosmilah $^{a}$ Murad Shahnaz $^{\mathrm{b}}$ Jones Meinir $^{\mathrm{d}}$ Arip Masita $^{\mathrm{b}}$ \\ Abdullah Noormalin $^{b}$ Mohamed Jamaluddin ${ }^{c}$ \\ aDepartment of Biology, Faculty of Science and Mathematics, Sultan Idris Education University, Tanjong Malim, Perak, and \\ ${ }^{b}$ Allergy and Immunology Research Centre, Institute for Medical Research, and ${ }^{\top}$ Faculty of Allied Health Sciences, Universiti \\ Kebangsaan Malaysia, Kuala Lumpur, Malaysia; ${ }^{\mathrm{d} O c c u p a t i o n a l ~ a n d ~ E n v i r o n m e n t a l ~ M e d i c i n e, ~ I m p e r i a l ~ C o l l e g e, ~ L o n d o n, ~ U K ~}$
}

\section{Key Words}

Fish allergy · Immunoblotting · Mass spectrometry · SDS-PAGE · Thunnus tonggol $\cdot$ Tuna $\cdot$ Two-dimensional electrophoresis

\begin{abstract}
Background: The longtail tuna (Thunnus tonggol) is widely consumed in Asia. Parvalbumin, the main major allergen of fish, has been well identified in multiple fish species, yet little is known about the allergenic proteins in T. tonggol. Thus, the aim of this study was to characterize the major allergens of T. tonggol using a proteomics approach. Methods: Raw and boiled extracts of the fish were prepared. Fish proteins were separated by means of SDS-PAGE and two-dimensional (2-DE) electrophoresis. 1-DE immunoblotting of raw extract was performed with sera from fish-allergic patients. Ten sera were further analysed by 2-DE immunoblotting. Selected major allergenic protein spots were excised, trypsin digested and analysed by means of mass spectrometry. $\boldsymbol{R e}$ sults: SDS-PAGE of raw extract revealed 26 protein fractions, while boiled extract demonstrated fewer bands. The 2-DE gel profile of the raw extract further fractionated the protein bands to more than 100 distinct protein spots. 1-DE immunoblotting of raw extract exhibited two thermolabile protein
\end{abstract}

fractions of 42 and $51 \mathrm{kDa}$ as the major allergens, while the boiled extract only revealed a single lgE-binding band at 151 $\mathrm{kDa}$. 2-DE immunoblotting of raw extract further detected numerous major IgE-reactive spots of 11-13, 42 and $51 \mathrm{kDa}$. Mass spectrometry analysis of the peptides generated from the 12, 42 and $51 \mathrm{kDa}$ digested spots indicated that these spots were parvalbumin, creatine kinase and enolase, respectively. Conclusions: In addition to parvalbumin, two new thermolabile allergens were identified as major allergenic proteins of $T$. tonggol. This study proved that both thermostable and thermolabile proteins are important in local tuna allergy and should be included in diagnostic strategies.

(c) 2013 S. Karger AG, Basel

\section{Introduction}

Tuna and tuna-like species are very important economically and a significant source of food [1]. True tuna belongs to the genus Thunnus that includes 8 species [1]. Longtail tuna, Thunnus tonggol (Bleeker) is the second smallest Thunnus spp. and grows to a maximum size of $142 \mathrm{~cm}$ total length and $35.9 \mathrm{~kg}$ [2]. The dorsal region of this fish is dark blue, and the lower region and abdomen

\section{KARGER}

E-Mail karger@karger.com

www.karger.com/iaa
(C) 2013 S. Karger AG, Basel

$1018-2438 / 13 / 1624-0299 \$ 38.00 / 0$
Correspondence to: Dr. Misnan Rosmilah

Department of Biology, Faculty of Science and Mathematics

Sultan Idris Education University

35900 Tanjong Malim, Perak (Malaysia)

E-Mail rosmilah@fsmt.upsi.edu.my 
silver-white with colourless elongated oval spots along the body [3]. Locally known as 'tongkol', 'kayu' or 'aya', this fish is an economically important pelagic species inhabiting tropical and subtropical countries of the IndoPacific region, throughout the Indian Ocean and western Pacific Ocean [1]. This fish is the most frequently caught tuna in peninsular Malaysia; the local catch reached 29,714 tonnes in 2010 , contributing to $48 \%$ of the total tuna landing in Peninsular Malaysia [4]. In Malaysia, this tuna is usually eaten fresh and a limited amount is canned for export [3].

However, proteins of the fish have been highlighted as potent allergens in sensitised children and adults, with clinical manifestations ranging from mild allergic responses to severe life-threatening anaphylactic reactions [5-8], especially in the coastal countries where fish consumption is high, such as Scandinavian countries and Japan [5]. Therefore, fish allergy has been listed as one of the 8 most frequent allergies, and the labelling of foods containing seafood including fish has already become mandatory in the USA, Europe and Japan, for example, which requires manufacturers to clearly list fish ingredients on product labels [6]. Various species of bony fish including tuna have also been updated as important seafood causing occupational allergy among seafood workers [9].

Our previous statistics showed that shellfish and fish were the most commonly implicated seafood in $44 \%$ of patients with asthma and allergic rhinitis [10]. Recent data from other Asian countries also emphasized seafood, particularly shellfish, and fish as an important allergens in up to $40 \%$ of children and $33 \%$ of adults [6]. Fish allergy was confirmed as a significant allergen in about $13 \%$ of children [11] and 4\% of adults in Singapore [12], 4-12\% among adults in India [13] and 1-3\% among children in Taiwan [14]. Importantly, fish allergy tends to be lifelong, similar to peanut allergy $[6,15]$.

Numerous fish allergens have been identified and characterized in a variety of fish species [6]. Most of these food allergens belong to parvalbumin, a calciumbinding sarcoplasmic protein with a molecular weight (MW) of about $12 \mathrm{kDa}[5,6,8,16]$. The first and bestidentified parvalbumin allergen is Gad c 1 from codfish Gadus callarias which has high cross-reactivity between different fish species $[6,17]$. In subsequent molecular studies, parvalbumin has been identified as major allergen in multiple species of fish, such as salmon [18], Atlantic cod [19], carp [20, 21], mackerel [22, 23], Alaska pollack [24], blunt snout bream [25] and red stingray [26]. In addition to parvalbumin, within the last several years some studies have identified higher-MW fish allergens, including aldehyde phosphate dehydrogenase [27], collagen [28-30], transferrin [31], enolase and creatine kinase [25].

Studies on tuna allergens have been conducted on several species of tuna such as Thunnus albacares/yellowtail tuna $[28,32,33]$, Thunnus alalunga/albacore $[16,32]$, Thunnus obesus/bigeye tuna $[29,30]$ and Thunnus thynnus/bluefin tuna [31], while some other studies did not mentioned the tuna species [34]. To the best of our knowledge, there is only one short report on T. tonggol [35]. Therefore, the aim of this study is to characterize and identify the major allergens of local tuna, $T$. tonggol, using a proteomics approach.

\section{Materials and Methods}

\section{Fish Protein Extraction}

Protein extraction was conducted according to our previous study [23] with modifications. T. tonggol was purchased from a local market at Port Klang (Malaysia). To recognize thermostable and thermolabile bands, two types of T. tonggol extracts (raw and boiled) were prepared from a mixture of white and dark muscles. In brief, the fish muscles ( $40 \mathrm{~g}$ ) were homogenized in $400 \mathrm{ml}$ of $0.1 \mathrm{M}$ phosphate-buffered saline ( $\mathrm{pH} 7.2$; diluted 1:10 in distilled water) using a Waring blender for $15 \mathrm{~min}$, followed by overnight extraction at $4^{\circ} \mathrm{C}$ under shaking. The fish homogenates were then clarified by centrifugation at 4,500 and 14,000 r.p.m., both for 15 min at $4^{\circ} \mathrm{C}$. The supernatant was collected, sterile filtered using a $0.22-\mu \mathrm{m}$ syringe filter, freeze dried and stored at $-20^{\circ} \mathrm{C}$ until use. In contrast, for boiled extract preparation, the homogenates were boiled on a hot plate for 15 min before being extracted as mentioned above. The protein content of the extracts was quantified using a total protein kit (Sigma, St. Louis, Mo., USA).

\section{Experimental Sera}

To identify IgE-binding proteins of T. tonggol, 67 sera from patients with a clinical history of fish allergy and positive skin prick test to raw extract of $T$. tonggol were used. The sera were obtained from patients referred to the Allergy Clinic, Kuala Lumpur Hospital, while several control sera were obtained from non-allergic subjects. The sera were stored at $-80^{\circ} \mathrm{C}$ until use. This study was approved by the Medical Research and Ethics Committee of the Ministry of Health Malaysia.

\section{SDS-PAGE Analysis}

SDS-PAGE (sodium dodecyl sulphate polyacrylamide gel electrophoresis) was carried out following a method described previously [23]. The fish extracts were denaturated by heating at $95^{\circ} \mathrm{C}$ for $4 \mathrm{~min}$ in SDS reducing buffer (containing $0.06 \mathrm{M}$ Tris- $\mathrm{HCl}, \mathrm{pH}$ $6.8,2 \%$ SDS, $5 \% \beta$-mercaptoethanol, $25 \%$ glycerol and $0.01 \%$ bromophenol blue). The aliquots of fish protein samples $(10 \mu \mathrm{g} / \mathrm{well})$ were then resolved in a $12.0 \%$ separating gel with a $4 \%$ stacking gel at $120 \mathrm{~mA}$ for $45 \mathrm{~min}$ using a Mini-PROTEAN 3 system (BioRad, Hercules, Calif., USA). MW markers (Precision Plus Protein standards; BioRad) were run as a reference along with samples. After 
running, the gels were stained by Coomassie brilliant blue R250 to visualise the protein bands. MW markers were used to determine MW of the bands using the Imaging Densitometer GS800 and Quantity One Software (BioRad).

\section{1-DE Immunoblot Analysis}

Immunoblotting of raw extract was performed using sera from 67 fish-allergic patients as mentioned above. Briefly, the fish proteins resolved by SDS-PAGE were first electrophoretically transferred from the gel onto a $0.45-\mu \mathrm{m}$ nitrocellulose membrane using a mini trans-blot System (BioRad) for $70 \mathrm{~min}$ at a constant voltage of $100 \mathrm{~V}$. The membrane was then rapidly stained with Ponceau $S$ to visualise the protein bands, cut into 3-mm-wide strips, washed with TTBS buffer (TBS buffer containing $0.05 \%$ Tween-20) and then blocked for $1 \mathrm{~h}$ with $10 \%$ non-fat milk in TBS (blocking buffer). After blocking, the strips were probed with individual patient sera overnight at $4^{\circ} \mathrm{C}$ under shaking, followed by incubation with biotinylated goat-anti-human IgE as the secondary antibody (KPL, Guildford, UK) for $30 \mathrm{~min}$. Finally, the strips were incubated in streptavidin-conjugated alkaline phosphatase (BioRad) for $30 \mathrm{~min}$ and alkaline phosphatase conjugate substrate kit (BioRad) for another $30 \mathrm{~min}$ to detect the IgE-binding proteins. To confirm the thermolabile properties of the IgE-binding proteins, immunoblotting of boiled extract was performed using sera from 10 patients identified to have specific IgE to raw T. tonggol in the immunoblotting above.

\section{Two-Dimensional Electrophoresis}

Two-dimensional electrophoresis (2-DE) gels were analysed using 7-cm immobilized dry strips (nonlinear, $\mathrm{pH} 3-10$; BioRad). Briefly, $50 \mu \mathrm{g}$ of the raw fish proteins were solubilised in rehydration buffer (containing $8 \mathrm{M}$ urea, $50 \mathrm{mM}$ DTT, 4\% CHAPS, $0.2 \%$ carrier ampholyte, $\mathrm{pH} 3-10$, and $0.0002 \%$ bromophenol blue). The strips were then rehydrated overnight with the rehydration buffer, followed by isoelectric focusing at $100 \mathrm{~V}$ for $1 \mathrm{~min}, 250 \mathrm{~V}$ for $30 \mathrm{~min}, 4,000 \mathrm{~V}$ for $2 \mathrm{~h}$ and $4,000 \mathrm{~V}$ for $10,000 \mathrm{~V}$-h using the PROTEAN IEF cell system (BioRad). After focusing, the strips were treated sequentially with equilibration buffers (containing $65 \mathrm{~mm}$ dithiothreitol and then $135 \mathrm{~mm}$ iodo-acetamide in $125 \mathrm{~mm}$ Tris- $\mathrm{HCl}, \mathrm{pH} 6.8,6 \mathrm{M}$ urea, $2 \%$ SDS, $30 \%$ glycerol and $0.01 \%$ bromophenol blue). The strips were then subjected to gradient $8-12 \%$ polyacrylamide gels and sealed with $1 \%$ agarose (containing 125 $\mathrm{mM}$ Tris- $\mathrm{HCl}, \mathrm{pH} 6.8$, and $0.1 \%$ SDS). Proteins were then resolved by MW using the Mini PROTEAN 3 system (BioRad), stained with Coomassie brilliant blue R250, scanned using Imaging Densitometer GS800 and analysed using PDQuest software (BioRad).

\section{2-DE Immunoblot Analysis}

IgE-binding spots were detected by immunoblotting of the 2-DE gel using sera from 10 patients identified to have specific IgE to $T$. tonggol in the immunoblotting above. In brief, the unstained 2-DE gels were electrotransferred onto nitrocellulose membranes, followed by the same protocol of immunoblotting as mentioned above.

\section{Mass Spectrometry Analysis}

Coomassie-stained protein bands corresponding to those that reacted to patient sera were excised, stained and subjected to reduction, carbamidomethylation and in-gel tryptic digestion using modified porcine trypsin (Promega, Madison, Wisc., USA) carried out on a MassPrep workstation (Micromass, Manchester, UK). Data of peptide mass fingerprints were obtained by MALDI-TOF instrument (Micromass) using a 5\% aliquot of the samples. The remaining samples were concentrated in a Speed Vac, reconstituted in 1\% formic acid (aqueous) and subjected to liquid chromatography tandem mass spectrometry, performed on a QTOF II instrument (Micromass) as previously reported [36]. The acquired tandem mass spectrometry spectra were searched against the MSDB database using the Mascot software (Matrix Science, London, UK).

\section{Results}

\section{SDS-PAGE Analysis}

SDS-PAGE of raw extract contains both heat-stabile and thermolabile proteins (fig. 1a). At least 26 protein bands over a wide MW range (between 175 and $6.5 \mathrm{kDa}$ ) were exhibited in the raw extract. In the boiled extract, approximately only 9 of the bands, including a $12 \mathrm{kDa}$ band, can still be visualised on SDS-PAGE gel, while the remaining bands between $16-25$ and $40-90 \mathrm{kDa}$ were missing (fig. 1b).

\section{1-DE Immunoblot Analysis}

Figure 1a and table 1 show 1-DE immunoblotting analysis of raw extract of the fish. Overall, all sera detected at least $1 \mathrm{IgE}$-binding protein. A total of $17 \mathrm{IgE}$-binding proteins, ranging in $\mathrm{MW}$ from 151 to $12 \mathrm{kDa}$, were detected by the various sera. Two protein bands with MW of 51 and $42 \mathrm{kDa}$ have been identified as the major allergens of this fish. The $51 \mathrm{kDa}$ band was recognized by IgE in 35 sera $(52.2 \%)$, while the $42 \mathrm{kDa}$ band was demonstrated by 37 sera (55.2\%). Both proteins were found to be sensitive to heat in SDS-PAGE profiles. Moreover, a $46-\mathrm{kDa}$ thermolabile band and a $36 \mathrm{kDa}$ thermostabile band were considered as potential minor allergens, as detected by 28.4 and $26.9 \%$ of the sera, respectively. In addition, other thermostabile bands, including a low-MW (LMW) protein of $12 \mathrm{kDa}$ and several high-MW (HMW) bands of 90,115 and $151 \mathrm{kDa}$, were also recognized as minor allergens with a very low frequency of detection (1.5-6.0\%).

Figure $1 \mathrm{~b}$ and table 2 show the immunoblotting results of boiled extract. The test detected only 1 thermostable IgE-binding band at $115 \mathrm{kDa}$.

\section{2-DE and 2-DE Immunoblot Analysis}

Protein bands of $10-51 \mathrm{kDa}$ of $T$. tonggol were further fractionated to more than 100 distinct protein spots between pIs of 4.0-7.0 (fig. 2a). The single band of $51 \mathrm{kDa}$ 


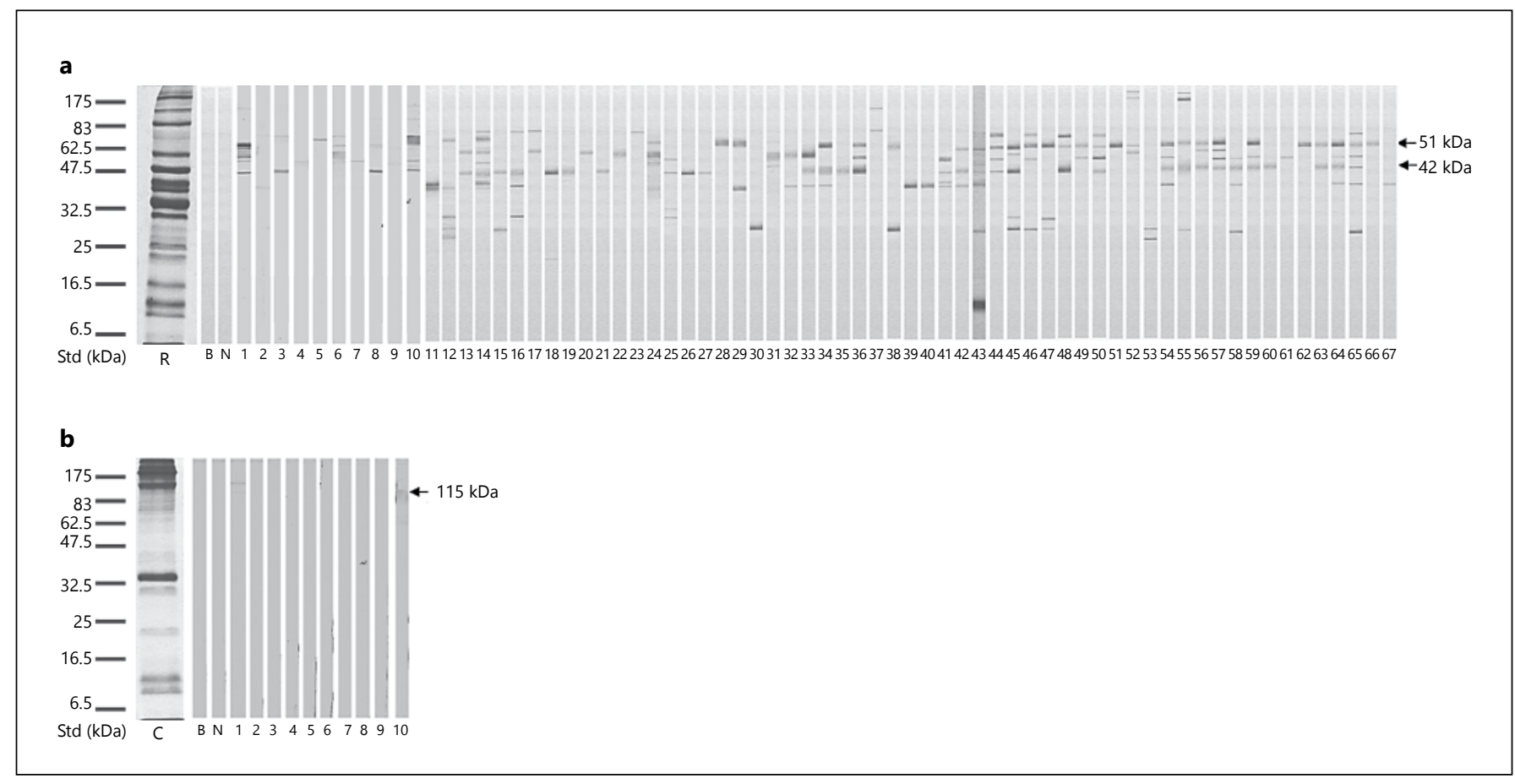

Fig. 1. SDS-PAGE gel and IgE immunoblotting results of raw (a) and boiled (b) T. tonggol proteins. R and C are SDS-PAGE profiles of raw and boiled extracts, respectively, and strips 1-67 are immunoblotting strips of sera from 67 fish-allergic patients. $\mathrm{B}=\mathrm{Blank}$; $\mathrm{N}=$ negative control; Std = MW markers. Arrows indicate the position of major allergens of T. tonggol (a) and the $\sim 115-\mathrm{kDa}$ protein $(\mathbf{b})$.

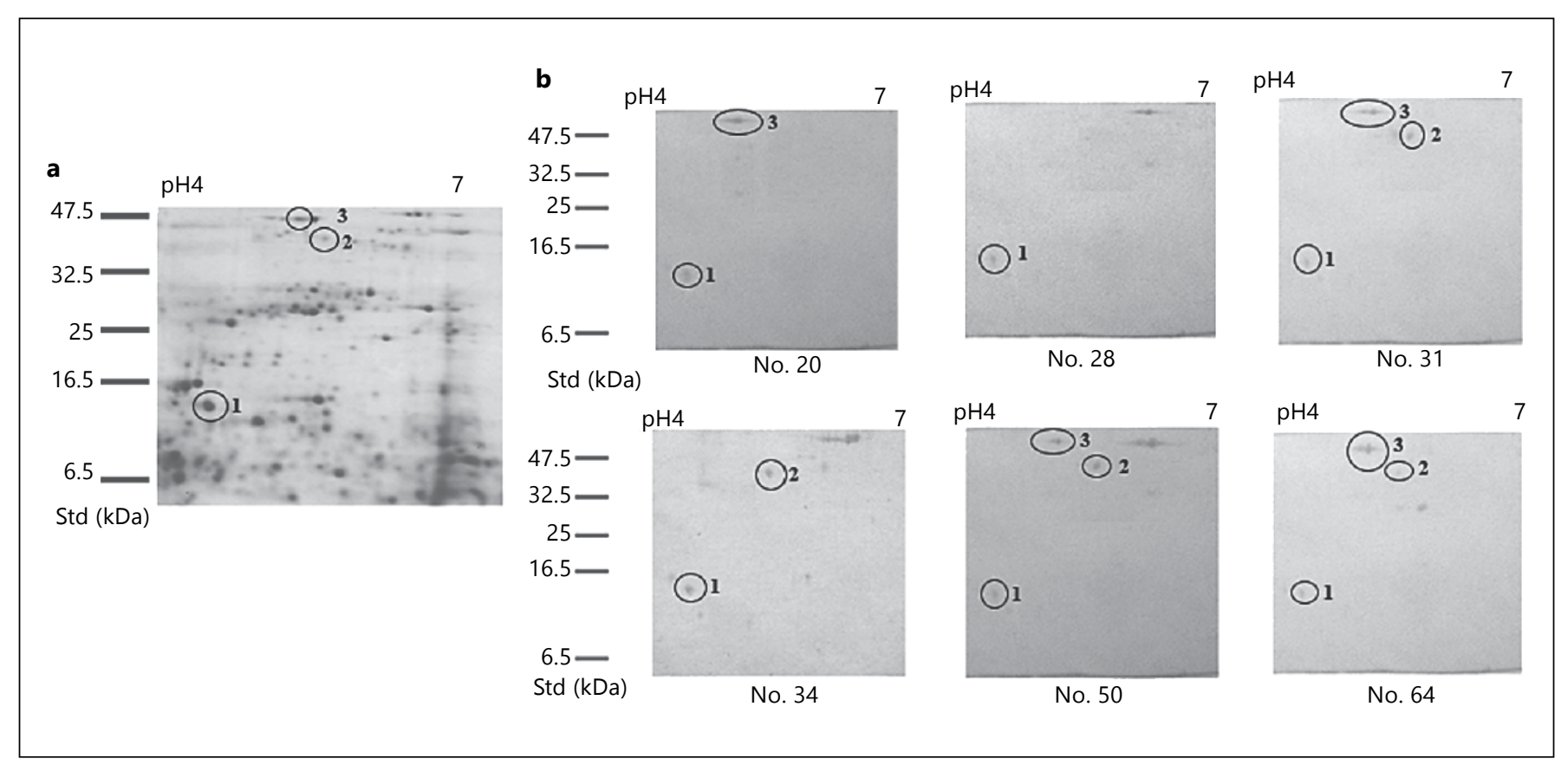

Fig. 2. a 2-DE gel stained with Coomassie blue. b Immunoblotting of 2-DE profiles of T. tonggol using sera from patients known to have specific IgE to the fish allergens (No. 20-64 correspond to the subjects listed in table 1). Std = MW; $\mathrm{pH}=$ approximate $\mathrm{pI}$ (along the top axis). All identified allergens are encircled and numbered (spots 1-3). 
Table 1. IgE immunoblotting analysis of raw T. tonggol using sera from 67 patients with fish allergy

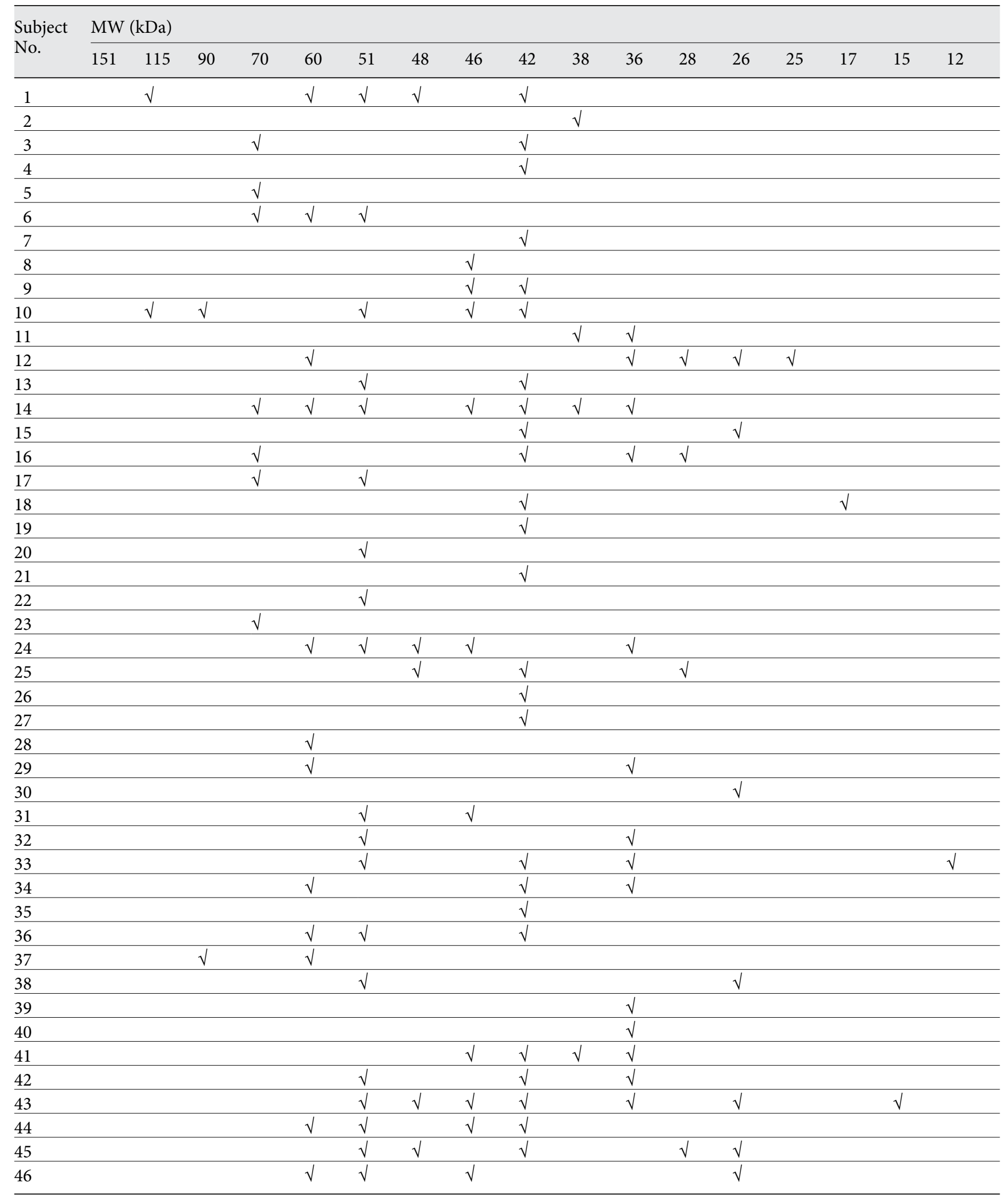


Table 1. (continued)

\begin{tabular}{|c|c|c|c|c|c|c|c|c|c|c|c|c|c|c|c|c|c|}
\hline \multirow{2}{*}{$\begin{array}{l}\text { Subject } \\
\text { No. }\end{array}$} & \multicolumn{17}{|c|}{ MW (kDa) } \\
\hline & 151 & 115 & 90 & 70 & 60 & 51 & 48 & 46 & 42 & 38 & 36 & 28 & 26 & 25 & 17 & 15 & 12 \\
\hline 47 & & & & & & $\sqrt{ }$ & & & & & & $\sqrt{ }$ & $\sqrt{ }$ & & & & \\
\hline 48 & & & & & $\sqrt{ }$ & $\sqrt{ }$ & & & $\sqrt{ }$ & & & & & & & & \\
\hline 49 & & & & & & $\sqrt{ }$ & & $\sqrt{ }$ & & & & & & & & & \\
\hline 50 & & & & & $\sqrt{ }$ & $\sqrt{ }$ & & $\sqrt{ }$ & $\sqrt{ }$ & & & & & & & & \\
\hline 51 & & & & & & $\sqrt{ }$ & & & & & & & & & & & \\
\hline 52 & $\sqrt{ }$ & $\sqrt{ }$ & & & & $\sqrt{ }$ & $\sqrt{ }$ & & & & & & & & & & \\
\hline 53 & & & & & & & & & & & & & $\sqrt{ }$ & $\sqrt{ }$ & & & \\
\hline 54 & & & & & & $\sqrt{ }$ & & $\sqrt{ }$ & $\sqrt{ }$ & & $\sqrt{ }$ & & & & & & \\
\hline 55 & $\sqrt{ }$ & $\sqrt{ }$ & & & & $\sqrt{ }$ & & & $\sqrt{ }$ & & & & $\sqrt{ }$ & & & & \\
\hline 56 & & & & & & $\sqrt{ }$ & $\sqrt{ }$ & & $\sqrt{ }$ & & & & & & & & \\
\hline 57 & & & & & & $\sqrt{ }$ & $\sqrt{ }$ & $\sqrt{ }$ & $\sqrt{ }$ & & & & & & & & \\
\hline 58 & & & & & & & & $\sqrt{ }$ & $\sqrt{ }$ & & $\sqrt{ }$ & & $\sqrt{ }$ & & & & \\
\hline 59 & & & & & & $\sqrt{ }$ & & $\sqrt{ }$ & $\sqrt{ }$ & & & & & & & & \\
\hline 60 & & & & & & & & & $\sqrt{ }$ & & & & & & & & \\
\hline 61 & & & & & & & & $\sqrt{ }$ & & & & & & & & & \\
\hline 62 & & & & & & $\sqrt{ }$ & & & & & & & & & & & \\
\hline 63 & & & & & & $\sqrt{ }$ & & & $\sqrt{ }$ & & & & & & & & \\
\hline 64 & & & & & & $\sqrt{ }$ & & $\sqrt{ }$ & $\sqrt{ }$ & $\sqrt{ }$ & & & & & & & \\
\hline 65 & & & & & $\sqrt{ }$ & $\sqrt{ }$ & & $\sqrt{ }$ & $\sqrt{ }$ & & $\sqrt{ }$ & & $\sqrt{ }$ & & & & \\
\hline 66 & & & & & & $\sqrt{ }$ & & & & & & & & & & & \\
\hline 67 & & & & & & & & & & & $\sqrt{ }$ & & & & & & \\
\hline Total $n$ & 2 & 4 & 2 & 7 & 15 & 35 & 8 & 19 & 37 & 5 & 18 & 5 & 12 & 2 & 1 & 1 & 1 \\
\hline$\%$ & 3.0 & 6.0 & 3.0 & 10.4 & 22.4 & 52.2 & 11.9 & 28.4 & 55.2 & 7.5 & 26.9 & 7.5 & 17.9 & 3.0 & 1.5 & 1.5 & 1.5 \\
\hline
\end{tabular}

Table 2. IgE immunoblotting analysis of boiled T. tonggol using sera from 10 patients with fish allergy

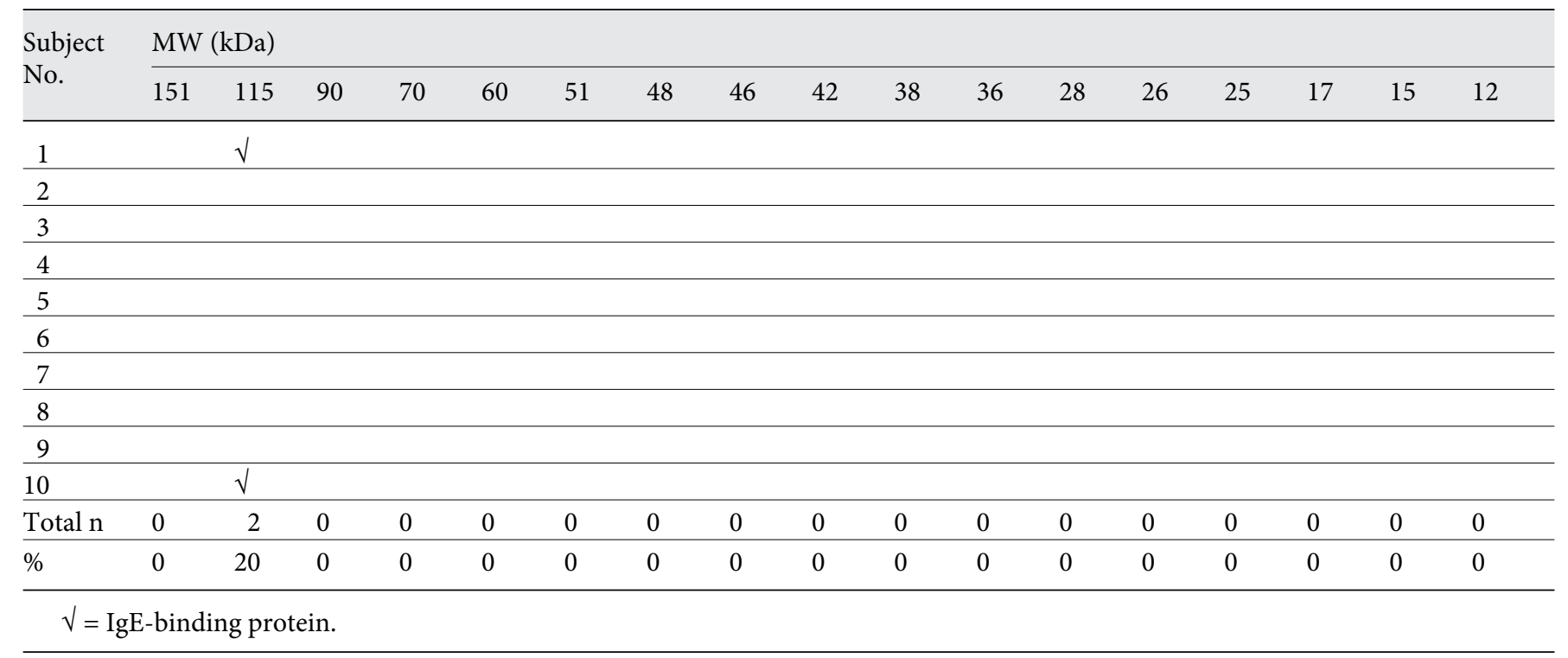


Table 3. Identification of major allergenic proteins of T. tonggol (spot no. 1-3) by mass spectrometry analysis

\begin{tabular}{|c|c|c|c|c|c|}
\hline $\begin{array}{l}\text { Spot } \\
\text { No. }\end{array}$ & $\begin{array}{l}\text { Observed } \\
\mathrm{MW} \\
\mathrm{kDa} / \mathrm{pI}\end{array}$ & Peptides/number of matched peptides & $\begin{array}{l}\text { Sequence } \\
\text { coverage, } \\
\%\end{array}$ & $\begin{array}{l}\text { Protein } \\
\text { identity }\end{array}$ & Homologous proteins \\
\hline 2 & $42 / 5.1$ & $\begin{array}{l}\text { TDLNFENLK, GGDDLDPNYVLSSR, GFTLPPHNSR, } \\
\text { DLLDPVISDR, GTGGVDTASVGGVFDISNADR, } \\
\text { LMVEMEK, GEAIDSMIPAQK, FCVGLQK/8 }\end{array}$ & $6-22$ & $\begin{array}{l}\text { creatine kinase } \\
\text { (EC 2.7.3.2) }\end{array}$ & $\begin{array}{l}\text { Q8JH38, Q6XGY4, Q9YI15, Q7T1J3, } \\
\text { Q804Z2, Q7T306 }\end{array}$ \\
\hline 3 & $51 / 5.3$ & $\begin{array}{l}\text { YDLDFK, KACNCLLLK, IGAEVYHNLK, ACNCLLLK, } \\
\text { VNQIGSVTESIQACK, AAVPSGASTGVHEALELR, } \\
\text { KFSVVEQEK, FMLELDGTENK, KACNCLLLK, } \\
\text { DATNVGDEGGFAPNILENNEALELLK, YNQLMR, } \\
\text { HIADLAGHK, EVILPVPAFNVINGGSHAGNK, } \\
\text { GGKYDLDFK/14 }\end{array}$ & $11-22$ & $\begin{array}{l}\text { enolase } \\
\text { (EC 1.1.1.17) }\end{array}$ & $\begin{array}{l}\text { Q9DDH0, Q6TH14, Q9PTX5, } \\
\text { Q9U5F7, Q7ZZM5, Q9DDH5, } \\
\text { Q9DDG7, ENO_XENLA, } \\
\text { ENO_ALLMI }\end{array}$ \\
\hline
\end{tabular}

was fractionated to at least 7 spots, while the $42 \mathrm{kDa}$ band was fractionated to approximately 11 spots. Numerous protein spots were also visualised in the LMW protein region of $10-13 \mathrm{kDa}$. Immunoblotting of 2-DE gels using sera from 10 different sera demonstrated that each patient had individual IgE antibodies with different binding capacities (fig. 2b). At least 5 different IgE-reactive spots were detected by each serum. Overall, at least 20 different spots between 6.5 and $175 \mathrm{kDa}$ were able to bind to IgE antibodies (data not shown). However, only several spots of 51 and $42 \mathrm{kDa}$ were exhibited as IgEbinding spots. Surprisingly, all sera were found to have specific IgE antibodies to LMW protein spots of 10$13 \mathrm{kDa}$.

\section{Mass Spectrometry Analysis}

This study focuses on further identification of the allergenic spots of 51 and $42 \mathrm{kDa}$ proteins, the major allergens of T. tonggol. However, the $12 \mathrm{kDa}$ protein was also further characterized as the protein spots were also recognized as the major IgE-binding spots in immunoblotting of 2-DE profiles. Table 3 summarized the results of mass spectrometry analysis of the spots. Sequence comparisons of a $51 \mathrm{kDa}$ spot (spot 3) and a $42 \mathrm{kDa}$ spot (spot 2 ) with known protein sequences in databases have identified these spots as fish enolase and creatine kinase, respectively, while the major allergenic spot of $12 \mathrm{kDa}$ (spot 1 ) is identical to parvalbumin of various species of fish including Sal s 1.

Parvalbumin and Thermolabile Major Allergens of T. tonggol

\section{Discussion}

Tuna plays an important role in nutrition worldwide, including Asian regions [6]. Characterization of new allergenic proteins could be effectively performed through recent advances in proteomics technology [17, 25, 37]. Thus, we used this approach to identify the allergenic proteins of local longtail tuna, T. tonggol.

Teleost fish, including tuna, has two types of muscles: white and dark muscles, and the allergenicity of the muscles mostly depends on the parvalbumin content $[5,38]$. Parvalbumin, the major and cross-reactive allergen in multiple fish species, is found more abundant in the white than in the dark muscle, and therefore the white muscle is more allergenic $[5,35,38]$. The parvalbumin content also varies significantly among different fish species $[5$, 38,39 ], and it was much lower in yellowtail tuna than in other species of fish $[5,38]$. It was also reported that Gad c 1 , Sal s 1, The c 1 , herring and wolffish contained the most potent cross-reacting allergens, whereas tuna, together with halibut, flounder, and mackerel, were the least allergenic fish [16]. Although it is thought that the dark muscle of the fish is less allergenic than the white muscle, we prepared the T. tonggol extracts from a mixture of white and dark muscles as the dark muscle is often ingested with the white muscle.

Comparison of SDS-PAGE results between raw and boiled extracts revealed that the boiling process has significantly modified the protein profiles of $T$. tonggol. The raw extract contains 26 protein fractions, generally sim- 
ilar to the protein profile of raw yellowtail tuna [28, 33], whereas the boiled extract has only 9 protein bands, probably due to denaturation of thermolabile proteins of $16-25$ and $40-90 \mathrm{kDa}$. This protein pattern is also in accordance with other studies which reported thermolabile proteins between $20-100$ [40] and $40-90 \mathrm{kDa}$ [41] in multiple fish species. Allergic reactions to fish most commonly occur upon ingestion of cooked fish $[6,8]$, but it can also be triggered by raw fish, particularly after direct contact with the raw fish, ingestion of raw or undercooked fish, or inhalation of fish odours or fumes, as proven by other researchers [41-43]. It was reported that almost $10 \%$ of patients with seafood allergy including fish have more severe reactions caused by inhalation or skin contact than by ingestion [44]. Therefore, in this study, the raw extract was selected to be used in skin prick and both 1-DE and 2-DE immunoblotting tests, predominantly to avoid missing IgE-binding proteins, as the raw extract contains both thermostable and thermolabile proteins, whereas the boiled extract comprises only a few thermostable bands. However, to confirm the thermostability properties of the bands, we repeated the 1-DE immunoblotting test with boiled extract using 10 sera.

Although T. tonggol contains numerous protein bands, only 17 bands are recognized as putative allergens based on the 1-DE immunoblotting results. Importantly, our study found that both groups of proteins (thermolabile and thermostable proteins) were able to bind with $\operatorname{IgE}$ antibodies of the tested sera, demonstrating that both proteins were significantly implicated in allergy to this fish. The thermolabile properties of the bands were also successfully confirmed by the immunoblotting results of boiled extract of the fish. Initially, seafood allergens are often reported as heat-stable proteins and therefore resist the effect of cooking, processing or digestive processes [17]. However, other findings have confirmed the presence of thermolabile allergenic proteins in multiple species of fish $[28,32,41]$, and canned tuna is considered the least-allergenic form of fish [33]. Hence, allergenicity of the thermolabile proteins seems to be reduced by heat (boiling, frying or grilling) [40,44], as well as by drying, salting, smoking and chemical processing [33].

In this study, more than half of the tested sera detected IgE-binding bands at 42 and $51 \mathrm{kDa}$, thus, these thermolabile proteins were identified as the major allergens of this local tuna. Mass spectrometry analysis of the peptide fragments isolated from the digested spots of 42 and 51 $\mathrm{kDa}$ were identical to the fish creatine kinase subunit and enolase fragment, respectively. Interestingly, a very re- cent finding by Liu et al. [25] also reported enolase and creatine kinase as new allergens of freshwater fish blunt snout bream, conforming well to our study.

Creatine kinase, also known as creatine phosphokinase, is an important enzyme expressed by various tissues, particularly tissues with high energy demands such as skeletal and cardiac muscles, neurons, photoreceptor cells, spermatozoa and electrocytes. This enzyme catalyses the reversible conversion of creatine and ATP to phosphokinase and ADP, thereby helping maintain energy homeostasis in the cells $[45,46]$. Creatine kinase, a dimeric enzyme with two identical subunits of approximately $40 \mathrm{kDa}$ as estimated by SDS-PAGE [47], is a highly conserved enzyme with a sequence that is $60 \%$ identical across all species [45], while arginine kinase, the creatine kinase homologue found in invertebrates including shellfish, is $\sim 45 \%$ identical and $~ 55 \%$ similar with various creatine kinase subunits [45]. Importantly, arginine kinase has been identified as the major allergen in multiple shellfish and invertebrates [48], whereas the creatine kinase subunit at $41 \mathrm{kDa}$ was recently discovered as an allergenic protein in a freshwater fish [25]. On the contrary, earlier investigation by Das Dores et al. [27] has also identified a new fish allergen at $41 \mathrm{kDa}$ in codfish, but as aldehyde phosphate dehydrogenase, a cytoplasmic enzyme involved in glycolysis and gluconeogenesis.

Enolase, a $51 \mathrm{kDa}$ major allergen, is also a ubiquitous cytoplasmic enzyme involved in glycolysis and gluconeogenesis [49]. Importantly, enolase (molecular mass ranging between 46 and $51 \mathrm{kDa}$ ) has been identified as a highly conserved allergen in fungal species and Hevea latex $[50,51]$. It should be pointed out that $\alpha$-enolase at $50-52 \mathrm{kDa}$ has been identified as an auto-antigen associated with severe asthma [52] and rheumatoid arthritis [53]. Therefore, the clinical relevance of enolase as well as creatine kinase in tuna allergy should be further investigated.

It should be noted that some earlier studies have reported HMW allergens at $34-38,40-42,45,46,50-51$ or $63 \mathrm{kDa}$ in multiple species of fish, including tuna, but they are not well characterized [16, 28, 32, 54-57]. Consistent with this, we have previously also reported major allergens at higher MW $(42,46$ and $51 \mathrm{kDa})$ in local snappers $[58]$ and mackerels $[23,59]$. Similarly, in addition to the major allergens at 42 and $51 \mathrm{kDa}$, we also found that more than one fourth of the tested sera indicated potential allergenic proteins of 36 and $46 \mathrm{kDa}$ of T. tonggol.

Immunoblotting of both 1-DE and 2-DE gels using sera from 67 and 10 different sera, respectively, demonstrated that each patient had individual IgE antibodies 
with different binding capacities and patterns. This divergent pattern of reactivity suggests that patients responded to both common and different antigenic epitopes. A significant relationship between symptoms and the epitope profiles in salmon-allergic patients has been observed recently [60], as well as in other allergic patients $[37,61,62]$. It was highlighted that IgE epitope mapping of allergens might provide information about the antigenic structure and a patient's immune response, and thereby has as a potential to become an additional tool for the diagnosis or prognosis of food allergy and for the development of safe hypo-allergenic immmunotherapeutic agents [60, 61 .

Overall, the results of 1-DE immunoblotting were in agreement with 2-DE immunoblotting findings except for several spots of LMW protein regions of $11-13 \mathrm{kDa}$. In 1-DE immunoblotting, the $12 \mathrm{kDa}$ band was only detected by 1 serum, but in 2-DE immunoblotting, all 10 sera demonstrated at least 3 allergenic spots of 11-13 $\mathrm{kDa}$. This could be due to the higher sensitivity of 2-DE immunoblotting than 1-DE immunoblotting as the 2-DE separation method has further fractionated the proteins to higher-resolution protein spots $[37,63]$, thereby probably rendering the protein epitopes more detectable by $\operatorname{IgE}$ antibodies of tested sera. It was reported that IgEbinding epitopes that were hidden within the protein may be uncovered in 1-DE immunoblotting [64]. As predicted, analysis of the peptide fragments isolated from 1 of the $12 \mathrm{kDa}$ spots revealed that this spot was homologous to the segments of multiple fish parvalbumin in the protein databases, indicating that parvalbumin is also a major allergenic protein of T. tonggol.

Besides parvalbumin, collagen and transferrin, HMW thermostable proteins were considered to be important fish allergens in several species of fish, including tuna $[29-31,34,39]$. However, in this study, only 4 sera (6.0\%) reacted to the HMW bands of 115 and $151 \mathrm{kDa}$, while only 2 sera $(3.0 \%)$ reacted to the $90 \mathrm{kDa}$ bands in $1-\mathrm{DE}$ immunoblotting. Notably, in this study, the raw extract was used in skin prick tests, therefore collagen, transferrin as well as parvalbumin may not be successfully detected as those proteins were significantly more reactive in the heated extracts $[29,31,39]$. For that reason, the use of boiled extracts in future studies should also be considered to avoid missing thermostable allergens.

In conclusion, we have characterized new major allergens from T. tonggol, creatine kinase and enolase, which are two thermolabile enzymes with a high level of homology in different animal species. In addition, parvalbumin, the well-documented thermostable fish allergen, was also identified as a major allergenic spot of this fish. Therefore, we suggest that both thermostable and thermolabile proteins are important in local tuna allergy and should be included in both in vivo and in vitro tests to avoid the potential of misdiagnosis. Moreover, the identification of all these major allergenic proteins is the first step toward generating recombinant allergens for use in future immunotherapeutic approaches.

\section{Acknowledgements}

We would like to thank the Director General of the Ministry of Health of Malaysia for the permission to publish this paper. The first author was a recipient of a National Science Fellowship Award from the Ministry of Science, Technology and Innovation of Malaysia. We also thank Prof. Graham Taylor and Miss Dinah Rahman (Imperial College) for their invaluable assistance in mass spectrometry analysis.

\section{References}

1 Food and Agriculture Organization of the United Nations: Biological characteristics of tuna. http://www.fao.org/fishery/topic/16082/ en (accessed January 17, 2012).

2 Griffiths SP, Fry GC, Manson FJ, Lou DC: Age and growth of longtail tuna (Thunnus tonggol) in tropical and temperate waters of the central Indo-Pacific. ICES J Mar Sci 2010;67: 125-134.

3 Mohsin AKM, Ambak MA: Marine Fishes and Fisheries of Malaysia and Neighbouring Countries. Serdang, Universiti Putra Malaysia, 1996.

4 Department of Fisheries Malaysia (DOF): Landings of marine fish by state and species, 2010; in List of annual fisheries statistics 2010. www.dof.gov.my/perangkaan2010 (accessed February 16, 2012).

5 Kobayashi A, Tanaka H, Hamada Y, Ishizaki S, Nagashima Y, Shiomi K: Comparison of allergenicity and allergens between fish white and dark muscles. Allergy 2006;61: 357-363.

-6 Lopata AL, Lehrer SB: New insights into seafood allergy. Curr Opin Allergy Clin Immunol 2009;9:270-277.

7 Mahoney EJ, Veling MC, Mims JW: Food allergy in adults and children. Otolaryngol Clin North Am 2011;44:815-833.

8 Taylor SL, Kabourek JL, Hefle SL: Fish allergy: fish and products thereof. J Food Sci 2004;69: 175-180.
-9 Jeebhay MF, Cartier A: Seafood workers and respiratory disease: an update. Curr Opin $\mathrm{Al}-$ lergy Clin Immunol 2010;10:104-113.

10 Shahnaz M, Gendeh BS, Nasuruddin A: Skin test reactivity to inhalant and food allergens in patients with allergic rhinitis. Int Med Res 2001;5:69-73.

11 Chiang WC, Kidon MI, Liew WK, Goh A, Tang JP, Chay OM: The changing face of food hypersensitivity in an Asian community. Clin Exp Allergy 2007;37:1055-1061.

12 Thong BY, Cheng YK, Leong KP, Tang CY, Chang HH: Immediate food hypersensitivity among adults attending a clinical immunology/allergy centre in Singapore. Singapore Med J 2007;48:236-240. 
13 Mandal J, Das M, Roy I, Chatterjee S, Barui NC, Gupta-Bhattacharya S: Immediate hypersensitivity to common food allergens: an investigation on food sensitization in respiratory allergic patients of Calcutta, India. World Allergy Organ J 2009;2:9-12.

14 Wan K, Yang W, Wu W: A survey of serum specific-IgE to common allergens in primary school children of Taipei City. Asian Pac J Allergy Immunol 2010;28:1-6.

15 Priftis KN, Mermiri D, Papadopoulou A, Papadopoulos M, Fretzayas A, Lagona E: Asthma symptoms and bronchial reactivity in school children sensitized to food allergens in infancy. J Asthma 2008;45:590-595.

$\checkmark 16$ Van Do T, Elsayed S, Florvaag E, Hordvik I, Endresen C: Allergy to fish parvalbumins: studies on the cross-reactivity of allergens from 9 commonly consumed fish. J Allergy Clin Immunol 2005;116:1314-1320.

$\checkmark 17$ Beyer K: Characterization of allergenic food proteins for improved diagnostic methods. Curr Opin Allergy Clin Immunol 2003;3: 189-197.

18 Van Do T, Hordvik I, Endresen C, Elsayed S: Expression and analysis of recombinant salmon parvalbumin, the major allergen in Atlantic salmon (Salmo salar). Scand J Immunol 1999;50:619-625.

19 Das Dores S, Chopin C, Romana A, GallandIrmouli AV, Quaratino D, Pascual J, Fleurence J, Gueant JL: A new oligomeric parvalbumin allergen of Atlantic cod ( Gad m1) encoded by a gene distinct from that of Gad c 1 . Allergy 2002;57:79-83.

20 Bugajska-Schretter A, Grote M, Vangelista L, Valent P, Sperr WR, Rumpold H, Pastore A, Reichelt R, Valenta R, Spitzauer S: Purification, biochemical and immunological characterisation of a major food alergen: different immunoglobulin E recognition of the apoand calcium-bound forms of carp parvalbumin. Gut 2000;46:661-669.

-21 Swobada I, Bugajska-Schretter A, Verdino P, Keller W, Sperr WR, Valent P, Valenta R, Spitzauer S: Recombinant carp parvalbumin, the major cross-reactive fish allergen: a tool for diagnosis and therapy of fish allergy. J Immunol 2002;168:4576-4584.

22 Hamada Y, Tanaka H, Ishizaki S, Ishida M, Nagashima Y, Shiomi K: Purification, reactivity with $\operatorname{IgE}$ and cDNA cloning of parvalbumin as the major allergen of mackerels. Food Chem Toxicol 2003;41:1149-1156.

23 Rosmilah M, Shahnaz M, Taylor G, Dinah R, Jones M, Masita A, Noormalin A, Jamaludin M: Identification of parvalbumin and other proteins as major allergens of Indian scad (Decapterus russelli, Ruppell). Asian Pac J Allergy Immunol 2008;26:191-198.

-24 Van Do T, Hordvik I, Endresen C, Elsayed S: Characterization of parvalbumin, the major allergen in Alaska pollack, and comparison with codfish allergen M. Mol Immunol 2005; 42:345-353.

25 Liu R, Krishnan HB, Xiue W, Liu C: Characterization of allergens isolated from the fresh- water fish blunt snout bream (Megalobrama amblycephala). J Agric Food Chem 2011;59: 458-463.

26 Cai QF, Liu GM, Li T, Hara K, Wang XC, Su WJ, Cao MJ: Purification and characterization of parvalbumins, the major allergens in red stingray (Dasyatis akajei). J Agric Food Chem 2010;58:12964-12969.

27 Das Dores S, Chopin C, Villaume C, Gueant JL: IgE-binding and cross-reactivity of a new $41 \mathrm{kDa}$ allergen of codfish. Allergy 2002;57: 79-83.

28 André F, Cavagna S, André C: Gelatin prepared from tuna skin: a risk factor for fish allergy or sensitization? Int Arch Allergy Immunol 2003;130:17-24.

29 Hamada Y, Nagashima Y, Shiomi K: Identification of collagen as a new fish allergen. Biosci Biotechnol Biochem 2001;65:285-291.

30 Hamada Y, Nagashima Y, Shiomi K, Shimojo N, Kohno Y, Shibata R, Nishima S, Ohsuna H, Ikezawa Z: Reactivity of IgE in fish-allergenic patients to fish muscle collagen. Allergol Int 2003;52:139-147.

31 Kondo Y, Komatsubara R, Nakajima Y, Yasuda T, Kakami M, Tsuge I, Urisu A: Parvalbu$\mathrm{min}$ is not responsible for crossreactivity between tuna and marlin. J Allergy Clin Immunol 2006;118:1382-1383.

32 Yamada S, Nolte H, Zychlinsky E: Identification and characterization of allergens in two species of tuna fish. Ann Allergy Asthma Immunol 1999;82:395-400.

33 Sletten G, Van Do T, Lindvik H, Egaas E: Effects of industrial processing on the immunogenicity of commonly ingested fish species. Int Arch Allergy Immunol 2010;151:223-236.

- 34 Sakaguchi M, Toda M, Ebihara T, Irie S, Hori H, Imai A, Yanagida M, Miyazawa H, Ohsuna $\mathrm{H}$, Ikezawa Z, Inouye S: IgE antibody to fish gelatin (type I collagen) in patients with fish allergy. J Allergy Clin Immunol 2000;106: 579-584.

35 Lim DL, Neo KH, Goh DL, Shek LP, Lee BW: Missing parvalbumin: implications in diagnostic testing for tuna allergy. J Allergy Clin Immunol 2005;115:874-875

36 Wilm M, Shevchenko A, Houthaeve T, Breit S, Schweigerer L, Fotsis T, Mann M: Femtomole sequencing of proteins from polyacrylamide gels by nano-electrospray mass spectrometry. Nature 1996;379:466-469.

37 Nair B, Wheeler JC, Sykes DE, Brown P, Reynolds JL, Aalinkeel R, Mahajan SD, Schwartz SA: Proteomic approach to evaluate mechanisms that contribute to food allergenicity: comparative 2D-DIGE analysis of radioallergosorbent test positive and negative patients. Int J Proteomics 2011;2011:673618.

38 Kuehn A, Scheuermann T, Hilger C, Hentges F: Important variations in parvalbumin content in common fish species: a factor possibly contributing to variable allergenicity. Int Arch Allergy Immunol 2010;153:359-366.

-39 Kanamori M, Tanaka H, Hamada Y, Nagashima Y, Shiomi K: New extraction method suitable for immunoblotting analysis of fish al- lergens. Eur Food Res Technol 2011;233:991997.

40 Chatterjee U, Mondal G, Chakraborti P, Patra HK, Chatterjee BP: Changes in the allergenicity during different preparations of pomfret, hilsa, bhetki and mackerel fish as illustrated by enzyme-linked immunosorbent assay and immunoblotting. Int Arch Allergy Immunol 2006;141:1-10.

41 Porcel S, Leon F, Cumplido J, Cuevas M, Guimaraens D, Conde-Salazar L: Contact urticaria caused by heat-sensitive raw fish allergens. Contact Dermatitis 2001;45:139-142.

42 Sugita K, Kabashima K, Nakashima D, Tokura Y: Oral allergy syndrome caused by raw fish in a Japanese sushi bar worker. Contact Dermatitis 2007;56:369-370.

43 Onesimo R, Giorgio V, Pili S, Monaco S, Sopo SM: Isolated contact urticaria caused by immunoglobulin E-mediated fish allergy. Isr Med Assoc J 2012;14:11-13.

44 Bahna SL: You can have fish allery and eat it too! J Allergy Clin Immunol 2004;114:125126

45 Lahiri SD, Wang P, Babbitt PC, McLeish MJ, Kenyon GL, Allen KN: The 2.1A structure of Torpedo california creatine kinase complexed with the ADP- $\mathrm{Mg}^{2+}-\mathrm{NO}_{3}{ }^{-}$creatine transition-state analogue complex. Biochemistry 2002;41:13861-13867.

46 Sun H, Liu C, Hui C, Wu J: The carp musclespecific sub-isoenzymes of creatine kinase form distinct dimers at different temperatures. Biochem J 2002;368:799-808.

47 Batista SCM, Nunes TN, Giovanni-De-Simone S, Nery MA, Hassón-Voloch A: Purification and partial characterization of creatine kinase from electric organ of Electrophorus electricus (L.). Int J Biochem Cell Biol 2000;32: 427-433.

48 Binder M, Mahler V, Hayek B, Sperr WR, Scholler M, Prozell S, Wiedermann G, Valent $\mathrm{P}$, Valenta R, Duchene M: Molecular and immunological characterization of arginine kinase from the Indianmeal moth, Plodia interpunctella, a novel cross-reactive invertebrate pan-allergen. J Immunol 2001;167:54705477.

49 Tracy MR, Hedges SB: Evolutionary history of the enolase gene family. Gene 2000;259: 129-138.

50 Simon-Nobbe B, Probst G, Kajava OH, Susani M, Crameri R, Ferreira F, Ebner C, Breitenbach M: IgE-binding epitopes of enolases, a class of highly conserved fungal allergens. J Allergy Clin Immunol 2000;106:887-895.

51 Wagner S, Breiteneder H, Simon-Nobbe B, Susani M, Krebitz M, Niggemann B, Brehler $\mathrm{R}$, Scheiner O, Hoffmann-Sommergruber K: Hev b 9, an enolase and a new cross-reactive allergen from Hevea latex and mould. Purification, characterization, cloning and expression. Eur J Biochem 2000;267:7006-7014.

-52 Nahm DH, Lee KH, Shin JY, Ye YM, Kang Y, Park HS: Identification of alpha-enolase as an autoantigen associated with severe asthma. J Allergy Clin Immunol 2006;118:376-381. 
53 Saulot V, Vittecoq O, Charlionet R, Fardellone P, Lange C, Marvin L, Machour N, Le Loet X, Gilbert D, Tron F: Presence of autoantibodies to the glycolytic enzyme $\alpha$-enolase in sera from patients with early rheumatoid arthritis. Arthritis Rheum 2002;46:11961201.

54 Das A, Chakraborti P, Chatterjee U, Monddal G, Chatterjee BP: Identification of allergens in Indian fishes: hilsa and pomfret exemplified by ELISA and immunoblotting. Indian J Exp Biol 2005;43:1170-1175.

55 Ebo DG, Kuehn A, Bridts CH, Hilger C, Hentges F, Stevens WJ: Monosensitivity to pangasius and tilapia caused by allergens other than parvalbumin. J Investig Allergol Clin Immunol 2010;20:84-88.

56 Bardina L, Vukic EJ, Sampson HA, Beyer K: Identification of additional allergens in cooked salmon (abstract). J Allergy Clin Immunol 2004;113:S237.
57 Mata E, Favier C, Moneret-Vautrin DA, Nicolas JP, Han CL, Gueant JL: Surimi and native codfish contain a common allergen identified as a $63 \mathrm{kDa}$ protein. Allergy 1994; 49:442-447.

58 Rosmilah M, Shahnaz M, Masita A, Noormalin A, Jamaludin M: Identification of major allergens of two species of local snappers: $\mathrm{Lu}$ tjanus argentimaculatus (merah/red snapper) and Lutjanus johnii (jenahak/golden snapper). Trop Biomed 2005;22:171-177.

59 Rosmilah M, Shahnaz M, Masita A, Noormalin A, Jamaludin M: Characterization of immunoglobulin E-binding proteins (IgE) of Scomberomorus commerson Lacepede. Malays J Health Sci 2005;3:79-87.
60 Perez-Gordo M, Lin J, Bardina L, Pastor-Vargas C, Cases B, Vivanco F, Cuesta-Herranz J, Sampson HA: Epitope mapping of Atlantic Salmon major allergen by peptide microarray immunoassay. Int Arch Allergy Immunol 2012;157:31-40.

61 Lin J, Sampson HA: The role of immunoglobulin E-binding epitopes in the characterization of food allergy. Curr Opin Allergy Clin Immunol 2009;9:357-363.

62 Robotham JM, Teuber SS, Sathe SK, Roux $\mathrm{KH}$ : Linear IgE epitope mapping of the English walnut (Juglans regia) major food allergen, Jug r 1. Allergy Clin Immunol 2002;109: 143-149.

-63 Benndorf D, Muller A, Bock K, Manuwald O, Herbarth $\mathrm{O}$, von Bergen M: Identification of spore allergens from the indoor mould Aspergillus versicolor. Allergy 2008;63:454-460.

-64 Shriver SK, Yang WW: Thermal and nonthermal methods for food allergen control. Food Eng Rev 2011;3:26-43. 